

\section{NOTICE}

This report was prepared as an account of work sponsored by the United States Government. Neither the United States nor the United States Atomic Energy Commission, nor any of their employees, nor any of their contractors, subcontractors, or their employees, makes any warranty, express or implied, or assumes any legal liability or responsibility for the accuracy, completeness or usefulness of any information, apparatus, product or process disclosed, or represents that its use would not infringe privately owned rights.

\begin{tabular}{|c|}
\hline Printed in the United States of America \\
Available from \\
National Technical Information Service \\
U. S. Department of Commerce \\
5285 Port Royal Road \\
Springfield, Virginia 22151 \\
Printed Copy \$4.00; Microfiche $\$ 1.45$ \\
Price:
\end{tabular}




\title{
SOLID FOTMS FOR SAVANNAH RIVER PLANT HIGH-LEVEL WASTE
}

\author{
by \\ R. M. Wallace \\ H. L. Hu11 \\ R. F. Bradley \\ Approved by \\ J. A. Porter, Research Manager \\ Separations Chemistry Division \\ and \\ A. S. Jennings, Research Manager \\ Separations Engineering Division \\ December 1973

\section{E. I. du Pont de Nemours \& Co. Savannah River Laboratory \\ Aiken, S. C. 29801}




\begin{abstract}
One option for long-term management of Savannah River Plant high-activity waste is solidification and storage in a retrievable surface storage facility to be located on the plantsite. This study was made to evaluate candidate solid waste forms and solidification processes, and to determine their applicability to engineered storage of Savannah River Plant waste. The study included: 1) characteristics of the present tank-stored waste, 2) criteria for acceptable long-term waste storage forms, 3) properties of potentially useful solid forms and the associated processes, and 4) evaluation of the potential product forms for Savannah River Plant waste.
\end{abstract}




\section{CONTENTS}

$\underline{\text { Page }}$

Introduction . . . . . . . . . . . . . 7

Summary . . . . . . . . . . . . . . 7

Characteristics of Savannah River Plant Waste. . . 9

Origins . . . . . . . . . . . . . . . . . . . 9

Waste Management Practices . . . . . . . . . 11

Chemical Composition ............. 11

Radioactivity and Toxicity . . . . . . . 12

Heat Generation . . . . . . . . . . 14

Criteria for Acceptable Waste Storage Forms . . . 16

Thermal Conductivity . . . . . . . . . 16

Leachabiiity . . . . . . . . . . . . . 17

Chemical and Radiation Stability . . . . . 20

Mechanical Strength ........... 20

Corrosiveness to Containers . . . . . . . 21

Minimum Volume . . . . . . . . . . . 21

Properties of Potentially Useful Solid Waste Forms and Associated Processes . . . . . . . . . . 21

Calcines . . . . . . . . . . . . . 21

Glasses and Ceramics........... . 23

Intermediate-Level Forms . . . . . . . . . . . 24

Asphalt .............. . 24

Cement . . . . . . . . . . . . 25

Evaluation of Product Forms for SRP Waste . . . . 26

Combined Wastes . . . . . . . . . . 26

Segregated Waste........... 28

Appendix - Equations for Leaching . . . . . . . 31

References . . . . . . . . . . . . . 35 


\section{LIST OF TABLES}

$\underline{\text { Page }}$

Table

I Average Chemical Composition of Waste . . . . 12

II Maximum Concentration of Various 13

Elements in Sludge .. . . . . . . . . .

III Amounts of Activity in Stored Waste

and Relative Toxicity Due to Radio-

nuclides and Other Components . . . . . . . 15

IV Relation Between Leach Rates and

Quantities Directly Related to Safety... . . 19

V Properties of Various Solid Waste Forms . . . 22

VI Evaluation of Product Forms for SRP Wastes . . 30 


\section{SOLID FORMS FOR \\ SAVANNAH RIVER PLANT \\ HIGH-LEVEL WASTE}

\section{INTRODUCTION}

One option for long-term management of Savannah River Plant (SRP) high-level radioactive waste is solidification and storage in a retrievable surface storage facility for 100 years or more. In similar facilities currently being designed for storing highlevel waste from commercial reprocessing of power reactor fuel, the waste will be stored as a glass or calcine in steel or stainless steel cylindrical containers that will be cooled by either water or air. Over the last two decades, much work has gone into the development of various solid forms for power reactor waste. The purpose of this report is to examine the applicability of these forms to SRP waste.

The approaci used in this study was first to investigace the characteristics of SRP wastes as they now exist and then to define tentative criteria for acceptable waste forms for engineered storage. A literature study was next made of the properties of potentially useful solid waste forms and of the processes that are used to prepare them. An evaluation of each of these waste forms was made by comparing their properties with the criteria for acceptance and by determining if the processes for making them were compatible with SRP waste.

\section{SUMMARY}

High-level radicactive waste solutions that originate in the two SRP separations plants are neutralized and stored in mild steel tanks as sludge, supernate, and salt cake. The sludge is composed principally of $\mathrm{Fe}(\mathrm{OH})_{3}$ and $\mathrm{MnO}_{2}$, but also contains many water-insoluble constituents such as $\mathrm{HgO}$. The salt cake (formed when aged supernate is evaporated) and the supernate contain the water-soluble constituents, principally $\mathrm{NaNO}_{3}, \mathrm{NaNO}_{2}, \mathrm{Na}_{2} \mathrm{SO}_{4}$, $\mathrm{NaOH}, \mathrm{Na}_{2} \mathrm{CO}_{3}$, and $\mathrm{NaAlO}_{2}$.

${ }^{90} \mathrm{Sr}$ and ${ }^{137} \mathrm{Cs}$ are the major sources of radiaoctivity, toxicity, and heat generation in SRP wastes for the 100 years or more storage period, although smaller amounts of many other radio- 
nuclides such as ${ }^{106} \mathrm{Ru}$ and ${ }^{239} \mathrm{Pu}$ will also be present. The ${ }^{90} \mathrm{Sr}$ resides mainly in the sludge, and the ${ }^{137} \mathrm{Cs}$ in the supernate and salt cake. For the purpose of this study, it has been assumed that the waste contains $200,000,000 \mathrm{Ci}$ each of ${ }^{90} \mathrm{Sr}$ and ${ }^{137} \mathrm{Cs}$ and $17,000 \mathrm{Ci}$ of ${ }^{239} \mathrm{Pu}$, and that when the salt cake is dissolved and the resulting solution mixed with sludge, $80,000,000$ gal of waste result. The average heat generation rate would be approximately 0.008 watt per liter.

The requirement for materials with good thermal properties in the solid form is not nearly as important for SRP waste as it is for power reactor waste because the power density in the former is much lower (by greater than one thousand times). Properties such as low leachability and high strength are more important.

Low leachability is important to the safety of a near-surface engineered storage facility because it reduces the consequences of any potential abnormal situation or accident in which a waste container might be breached and contacted with water. Additional properties of the solid that are important in relation to the safety of engineered storage include:

- Resistance to dispersion in air

- Chemical, thermal, and radiation stability

- Mechanical ruggedness

- Noncorrosiveness to container

Minimum volume is desirable only because it minimizes the cost of engineered storage.

Calcines $\left(\mathrm{NaNO}_{3}, \mathrm{Na}_{2} \mathrm{SO}_{4}, \mathrm{Na}_{2} \mathrm{O}\right)$ have undesirably high leach rates. Glasses are generally suitable products, but the presence of mercury, sulfate, and fluoride in SRP waste will interfere with the production of glasses: mercury will interfere because of volatilization and pluggage, and sulfate and fluoride because of corrosion. Glass production processes operate at high temperatures and require extensive off-gas treatment because of the production of volatile oxides of ruthenium as well as entrained radionuclides.

The leachability of devitrified phosphate glass is marginally acceptable. Borosilicate glasses will not dissolve sulfates, which float to the melt surface in processing and form a highly leachable separate phase. Aluminosilicates are the least leachable of the glasses, but techniques for their production are still under development. Production of glass from SRP waste would be facilitated if the sludge and supernate were separated and the cesium were sorbed on zeolite. Mercury, ruthenium, and possibly some sulfate in the sludge would still pose problems. 
Asphalt can probably be used to incorporate radionuclides in sludges or other insoluble materials into highly unleachable solids. However, the asphalt matrix would soften and melt at low temperatures and is flamable. The radiation stability of asphalt beyond $10^{9}$ rads is doubtful.

Cement can be used to solidify both sludge and supernate. The presence of large quantities of soluble salts in the supernate, however, will render the cement very leachable. If the sludge and supernate were separated and the cesium in the supernate was removed by sorption on zeolite, the sludge and the zeolite could be incorporated in the proper type of cement to yield a product of very low leachability. Such products could probably meet other anticipated criteria such as mechanical ruggedness, noncorrosiveness to the container, etc. Solidification with cement involves well-known low temperature mixing operations.

\section{CHARACTERISTICS OF SAVANNAH RIVER PLANT WASTE}

Origins

Most of the radioactive waste at SRP originates in the two separations plants; some waste is produced in the reactor areas, laboratories, and peripheral operations. The principal processes employed in the separations plants have been the Purex and the $\mathrm{HM}^{*}$ processes, but others have been used to process a variety of fuel and target elements. The Purex process recovers and purifies uranium and plutonium from neutron-irradiated natural uranium. The HM process recovers enriched uranium from uranium-aluminum alloys used as fuel in Savannah River reactors. Other processes that have been employed include: recovery of ${ }^{2}{ }^{3} \mathrm{U}$ and thorium from neutron-irradiated thorium, recovery of ${ }^{237} \mathrm{~Np}$ and ${ }^{238} \mathrm{Pu}$, separation of higher actinide elements from irradiated plutonium, and recovery of enriched uranium from stainless steelclad fuel elements from power reactors. Each of these processes produces a characteristic waste.

Some processes at SRP incorporate a chemical decladding step to remove the protective aluminum jackets from fuel and target elements. Furthermore, many chemicals have been used in the separations processes. Hence, SRP radioactive waste contains large amounts of many different nonradioactive materials. The origin of much of this material will be illustrated by brief descriptions of the Purex and HM processes.

* Process for recovering uranium from an aluminum-enriched uranium alloy. 
In the Purex process, the aluminum cladding of the uranium metal fuel elements is dissolved in a solution of sodium hydroxide and sodium nitrate. The resulting solution (coating waste) contains only small amounts of radionuclides and is transferred to low-level uncooled waste tanks for storage. The irradiated uranium is then dissolved in nitric acid; at times a head-end step is used in which some of the ${ }^{95} \mathrm{Zr}$ and ${ }^{95} \mathrm{Nb}$ is removed by sorption on freshly precipitated manganese dioxide. The uranium and plutonium are separated from the fission products and each other by two cycles of solvent extraction with tri-n-butyl phosphate (TBP). During the solvent extraction processes, chemicals such as sodium nitrite and ferrous sulfamate are added to adjust the oxidation state of plutonium. These chemicals later appear in neutralized waste as sodium nitrate, sodium sulfate, and ferric hydroxide. The waste from the first cycle of solvent extraction (high-1evel waste**) contains the bulk of the fission products and small amounts of uranium, plutonium, and higher actinide elements. This waste is evaporated to reduce its volume, neutralized with sodium hydroxide, and transferred along with a slurry of the head-end manganese dioxide to cooled, high-level waste tanks made of mild steel. The waste from the second cycle, which contains only low levels of radioactivity, is also evaporated and neutralized but is transferred to either cooled or uncooled tanks, depending on the activity level. The uncooled tanks are also fabricated of mild stee1.

In the HM process, fuel elements consisting of uraniumaluminum alloy clad in aluminum are dissolved in nitric acid with the aid of mercury as a catalyst. The uranium is recovered and decontaminated from fission products by two cycles of solvent extraction with TBP. Additional aluminum is added in the HM process to enhance the extraction of uranium; this adds considerably to the waste volume. The high-level and low-level wastes are evaporated, neutralized, and transferred to waste tanks as in the Purex process. After neutralization, most of the aluminum nitrate is converted to sodium nitrate and sodium aluminate.

\footnotetext{
**High-1evel refers to wastes that originate in the first solvent extraction cycle and in the head-end step. These wastes initially produce decay heat of 0.04 to $0.4 \mathrm{w} / 1[0.5$ to 5.0 $\mathrm{BTU} /(\mathrm{hr}-\mathrm{gal})]$. Low-level wastes have a fission product content of $1 / 1000$ to $1 / 10,000$ that of high-level wastes. Later in this report, the term high-level will be used in connection with power reactor wastes to refer to wastes with power densities of about $100 \mathrm{w} / 1$.
} 
Waste Management Practices

After waste is neutralized and transferred to tanks, manganese dioxide, ferric hydroxide, and other insoluble hydroxides and hydrous oxides (including those of fission products) settle to form a sludge layer. The volume of the sludge is about $10 \%$ of the total waste volume. The high-leve 1 wastes remain in cooled tanks for several years until the short-lived fission products decay. The supernatant solutions are then transferred to other tanks that contain little sludge. In recent years, aged supernatant solutions have been evaporated and returned to cooled tanks where much of the salt crystallizes. This procedure reduces the waste volume and conserves tank space; it also renders the waste less mobile and hence safer than if all liquid. Thus, the waste tanks contain sludge, water-soluble crystalline salts, and supernatant solutions. In further discussions on chemical and radiochemical composition, the crystalline salts and the supernate will be considered together because removal from the tanks will require dissolution of the salt in water and mixing with the existing supernate.

Transfers of waste from one tank to another have resulted in the mixing of the sludges and supernates of high- and low-level waste. Thus, for long-term management pirmoses the distinction between high- and low-level waste at SRP has almost vanished.

\section{Chemical Composition}

A completely valid generalization about the composition of SRP wastc cannot be made because large variations in the composition of both the sludge and the supernate occur from tank to tank, within a tank, and with time. For present purposes, it is sufficient to list the components that are present and estimate their maximum and average concentrations. The major chemical components of the wastes are $\mathrm{NaNO}_{3}, \mathrm{NaNO}_{2}, \mathrm{NaOH}, \mathrm{Na}_{2} \mathrm{CO}_{3}, \mathrm{Na}_{2} \mathrm{SO}_{4}, \mathrm{NaAlO}_{2}, \mathrm{Fe}(\mathrm{OH})_{3}$, and $\mathrm{MnO}_{2}$. The iron and manganese compounds are insoluble in an alkaline medium and are found in the sludge layer. If there is insufficient $\mathrm{NaOH}$ present to keep all of the aluminum in solution, a portion will precipitate as $\mathrm{Al}(\mathrm{OH})_{3}$. The other compounds are found mainly in the supernate. An estimate of the average chemical composition of the waste is given in Table $I$. This composition assumes that all the sludge constituents are uniformly distributed through the waste, and all the supernate, sludge, and salt cake from all of the storage tanks are blended with enough water to dissolve the salt cake. 
TABLE I. Average Chemical Composition of Waste

\begin{tabular}{cc} 
Constituent & Concentration, $M$ \\
\cline { 2 - 2 } $\mathrm{NaNO}_{3}$ & 2.2 \\
$\mathrm{NaNO}_{2}$ & 1.1 \\
$\mathrm{NaAlO}_{2}$ & 0.8 \\
$\mathrm{NaOH}$ & 0.5 \\
$\mathrm{Na}_{2} \mathrm{CO}_{3}$ & 0.3 \\
$\mathrm{Na}_{2} \mathrm{SO}_{4}$ & 0.3 \\
$\mathrm{Fe}(\mathrm{OH})_{3}$ & 0.15 \\
$\mathrm{MnO}_{2}$ & 0.02 \\
$\mathrm{NaF}$ & 0.02 \\
$\mathrm{Na}_{3} \mathrm{PO}$ & 0.01 \\
$\mathrm{NaCl}$ & 0.01 \\
$\mathrm{KNO}$ & 0.01 \\
$\mathrm{Ca}(\mathrm{OH})_{2}$ & 0.006 \\
$\mathrm{Hg}(\mathrm{OH})_{2}$ & 0.002 \\
$\mathrm{Mg}(\mathrm{OH})_{2}$ & 0.001 \\
$\mathrm{NaI}$ & 0.0002
\end{tabular}

Table II lists elements that have been detected or are known to be in the sludge and estimates their maximum concentration. Table II does not represent an average sludge or even any particular one. Many of the components listed will not be present in most sludges. The concentrations shown are the highest found in any sludge or the highest calculated to be present from the amount of material known to have been placed in waste tanks.

\section{Radioactivity and Toxicity}

When waste is first transferred into the storage tanks, it contains a number of short-lived isotopes that make the waste highly radioactive. These nuclides decay on standing, rendering the waste less active. It is presumed that the waste will be at least ten years old before it is solidified, and thus only radionuclides that contribute significantly to the activity at that and later times have to be considered. 
TABLE II. Maximum Concentration of Various Elements in Sludge

\begin{tabular}{|c|c|}
\hline Ezement & Centrifuged Sludge, $g / l$ \\
\hline Aluminum & 53.6 \\
\hline Barium & 6.1 \\
\hline Calcium & 4.5 \\
\hline Cerium & 4.7 \\
\hline Chlorine & 0.2 \\
\hline Chromium & 1.2 \\
\hline Cobalt & 0.1 \\
\hline Copper & 1.8 \\
\hline Iron & 75.0 \\
\hline Lanthanum & 1.9 \\
\hline Lead & 11.1 \\
\hline Magnesium & 1.3 \\
\hline Manganese & 45.0 \\
\hline Mercury & 30.0 \\
\hline Molybdenum & 0.3 \\
\hline Neodymium & 11.6 \\
\hline Nickel & 21.0 \\
\hline Phosphorus & 1.1 \\
\hline Potassium & 0.2 \\
\hline Praseodymium & 1.9 \\
\hline Promethium & 0.9 \\
\hline Ruthenium & 1.8 \\
\hline Silicon & 4.0 \\
\hline Silver & 0.045 \\
\hline Sodium & 50.0 \\
\hline Sulfur & 2.9 \\
\hline Tin & 0.4 \\
\hline Titanium & 0.3 \\
\hline Uranium & 86.6 \\
\hline Yttrium & 0.7 \\
\hline Zirconium & 5.0 \\
\hline
\end{tabular}


Table III contains a list of the radionuclides of concern in aged waste, their half-lives, the expected activity from each after ten years aging, and the relative toxicity of each.* The activities and relative toxicities shown in the table were calculated from data and by the procedure given in Reference 1 . The isotopes are listed in order of their relative toxicity; mercury and nitratenitrite are included because their toxicity is actually greater than that of many of the radioactive nuclides.

${ }^{90} \mathrm{Sr}$ and ${ }^{137} \mathrm{Cs}$ are by far the most active and hazardous radionuclides. Based on maximum permissible concentrations given in Reference 1 for public zone water, strontium is more than fifty times as hazardous as cesium. Strontium will be found primarily in the sludge, while cesium will be primarily in the supernate. However, sludge is a gelatinous precipitate containing trapped supernate, and about $10 \%$ of the cesium will therefore accompany the sludge. Of the other elements, promethium, plutonium, cesium, samarium, mercury, zirconium, and terbium will probably be in the sludge; iodine, technetium, selenium, and niobium will probably reside in the supernate; and ruthenium and palladium will probably be distributed between the two phases.

\section{Heat Generation}

The heat release that accompanies radioactive decay causes the waste to be self-heating. The heat generation in fresh wastes may be as high as $0.4 \mathrm{w} / 1$; over $90 \%$ of the heat generation is associated with the sludge because nearly all of the fission products except cesium and ruthenium are insoluble in alkaline solution. ${ }^{1{ }^{37}} \mathrm{Cs}$ and ${ }^{90} \mathrm{Sr}$ are each present at an average concentration of approximately $0.66 \mathrm{Ci} / 1(2.5 \mathrm{Ci} / g a 1)$. The average heat generation rate due to these nuclides is $0.0076 \mathrm{w} / 1$ $[0.096 \mathrm{BTU} /(\mathrm{hr}-\mathrm{gal})], 60 \%$ of which occurs in the sludge.

* Relative toxicity. is defined as the ratio of the concentration of a given isotope in the waste to its maximum permissible concentration in public zone water. This analysis assumes that every radionuclide in the waste is distributed homogeneously and that the total volume of waste is $8 \times 10^{7} \mathrm{gal}$. 
TABLE III. Amounts of Activity in Stored Waste and

Relative Toxicity Due to Radionuclides and Other Components

\begin{tabular}{|c|c|c|c|}
\hline Isotope & $\begin{array}{l}\text { Half-Life, } \\
\text { years }\end{array}$ & $\begin{array}{l}\text { Total Activity, } \\
\text { Ci }\end{array}$ & $\begin{array}{l}\text { Felative } \\
\text { Toxicity }\end{array}$ \\
\hline${ }^{90} \mathrm{Sr}$ & 28.8 & $2.0 \times 10^{\theta}$ & $2 \times 10^{9}$ \\
\hline${ }^{137} \mathrm{Cs}$ & 30.0 & $2.0 \times 10^{8}$ & $3 \times 10^{7}$ \\
\hline${ }^{14}{ }^{7} \mathrm{Pm}$ & 2.6 & $6.7 \times 10^{7}$ & $1 \times 10^{6}$ \\
\hline${ }^{106} \mathrm{Ru}$ & 1.0 & $3.5 \times 10^{5}$ & $1 \times 10^{5}$ \\
\hline${ }^{23 \theta} \mathrm{Pu}$ & 89 & $1.7 \times 10^{5}$ & $1 \times 10^{5}$ \\
\hline${ }^{244} \mathrm{Cm}$ & 18.1 & $1.2 \times 10^{5}$ & $6 \times 10^{4}$ \\
\hline${ }^{151} \mathrm{Sm}$ & 90 & $4.6 \times 10^{6}$ & $4 \times 10^{4}$ \\
\hline $\mathrm{Hg}$ (Inactive) & - & - & $2 \times 10^{4}$ \\
\hline $239 \mathrm{Pu}$ & $2.4 \times 10^{4}$ & $1.7 \times 10^{4}$ & $1 \times 10^{4}$ \\
\hline $\mathrm{NO}_{3}{ }^{-}+\mathrm{NO}_{2}-($ Inactive $)$ & 一 & - & $6 \times 10^{3}$ \\
\hline${ }^{129} \mathrm{I}$ & $1.6 \times 10^{7}$ & 31 & $1.7 \times 10^{3}$ \\
\hline${ }^{99} \mathrm{Tc}$ & $2.1 \times 10^{5}$ & $3.0 \times 10^{4}$ & 300 \\
\hline${ }^{79} \mathrm{Se}$ & $7 \times 10^{4}$ & 280 & 120 \\
\hline${ }^{135} \mathrm{Cs}$ & $2.0 \times 10^{6}$ & $3.1 \times 10^{3}$ & 100 \\
\hline${ }^{126} \mathrm{Sn}$ & $10^{5}$ & $1 \times 10^{3}$ & 100 \\
\hline${ }^{93} \mathrm{Zr}$ & $9.5 \times 10^{5}$ & $6.7 \times 10^{3}$ & 30 \\
\hline${ }^{94} \mathrm{Nb}$ & $2 \times 10^{4}$ & 3.2 & 13 \\
\hline${ }^{107} \mathrm{Pd}$ & $7 \times 10^{6}$ & 26 & 3 \\
\hline $158 \mathrm{~Tb}$ & 150 & 0.5 & $4 \times 10^{-5}$ \\
\hline
\end{tabular}

a. These quantities were assumed as a basis for this report and do not represent the actual quantities (classified) to be processed

b. Ratio of concentration in waste to maximum permissible concentration in public zone water. 


\section{CRITERIA FOR ACCEPTABLE WASTE STORAGE FORMS}

To provide a basis for evaluating the applicability of various solid waste forms for engineered storage, properties of solid waste forms related to the safety and economy of an engineered storage facility were identified and evaluated. This evaluation provided tentative criteria for the properties of solid waste forms; these criteria, however, give only the approximate magnitude desired for these properties and are not definitive requirements.

In a recent article, Schneider ${ }^{2}$ listed the properties that are considered of primary importance to the safety or economy of solidified power reactor wastes. These are:

- High thermal conductivity

- Low leachability

- Good chemical and radiation stability

- Mechanical ruggedness

- Noncorrosiveness to container

- Minimum volume

- Minimum cost

Each of these properties wi.ll be discussed as they relate to the storage of SRP wastes. For the purposes of this discussion, it is assumed that the SRP storage facility will house cylindrical containers of waste cooled by air and/or conduction to the ground.

\section{Thermal Conductivity}

High thermal conductivity is not nearly as-important for SRP waste as it is for waste from power reactors. The power density in solidified power reactor waste is expected to be about 100 w/1. ${ }^{3}$ Solidified SRP wastes, because of the large amounts of inert material, will have an average power density of only about $0.008 \mathrm{w} / 1$ (based on $2 \times 10^{8} \mathrm{Ci}$ each of ${ }^{13^{7}} \mathrm{Cs}$ and ${ }^{90} \mathrm{Sr}$ in $8 \times 10^{7}$ gal).

High thermal conductivity is necessary in solidified power reactor wastes to keep the centerline temperature of cylinders below the melting point. The steady-state difference between the centerline and wall temperature $\left(\mathrm{T}_{\mathrm{c}}-\mathrm{T}_{\mathrm{W}}\right)$ of a self-heating cylinder is given by the equation: ${ }^{4}$

$$
\mathrm{T}_{\mathrm{C}}-\mathrm{T}_{\mathrm{W}}=\frac{\mathrm{Ar}^{2}}{4 \mathrm{~K}}
$$

where

$$
\begin{aligned}
& \mathrm{A}=\text { heat generation rate/unit volume, } \\
& \mathrm{K}=\text { thermal conductivity, and } \\
& \mathrm{r}=\text { radius of the cylinder }
\end{aligned}
$$


A typical cylinder of glass made from power reactor waste ${ }^{2}$ might have a radius of six inches $(15 \mathrm{~cm})$, a thermal conductivity of $1 \mathrm{Btu} /\left(\mathrm{hr}-\mathrm{ft}-{ }^{\circ} \mathrm{F}\right)$ or $0.0041 \mathrm{cal} /\left(\mathrm{sec}-\mathrm{cm}-{ }^{\circ} \mathrm{C}\right)$, and a power density of $100 \mathrm{w} / 1$ or $0.024 \mathrm{cal} /\left(\mathrm{sec}-\mathrm{cm}^{3}\right)$, so that $\mathrm{T}_{\mathrm{C}}-\mathrm{T}_{\mathrm{W}}=330^{\circ} \mathrm{C}$. SRP waste with a power density of $0.008 \mathrm{w} / 1$ made into the same glass would have a centerline to wall temperature differential, $T_{C}-T_{W}$ of $0.027^{\circ} \mathrm{C}$. Even if the SRP waste (homogenized) were concentrated ten times and placed in a matrix with a thermal conductivity one-tenth that of glass, $\mathrm{T}_{C}-\mathrm{T}_{\mathrm{W}}$ would be only $2.7^{\circ} \mathrm{C}$. High thermal conductivity is therefore not of primary importance with SRP waste unless the activity were concentrated by one thousand. times.

Thermal stability is a more important requirement of solid forms for SRP waste than is high thermal conductivity. Thermal stability implies the ability of the solid form to withstand over long time periods the temperatures attained due to its own heat generation, or the ability to withstand higher temperatures that could be caused by external fires.

\section{Leachability}

Low leachability is inportant in case of an accident. Under normal operating conditions, the solidified waste would remain in its containers out of contact with water. For waste to be leached, the containers must be ruptured and the contents must come in contact with water, as in an explosion followed by a flood or rainstorm. Low leachability will improve safety by reducing the consequences of a major accident. With low-leachable forms, more time is available to take remedial action after an accident before activity release exceeds an acceptable level; as a corollary, the magnitude of an accident that can occur and not release unacceptable amounts of activity is increased.

An attempt was made to quantify these factors by relating

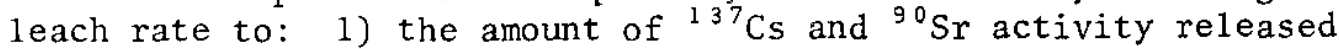
in a severe accident, 2) the time available to react to a severe accident before excessive amounts of activity are released, and 3 ) the numbers of containers that must be ruptured in a severe accident before releasing excessive amounts of activity. Pertinent equations are derived in the Appendix.

Leach rates are usually expressed in $\mathrm{g} /\left(\mathrm{cm}^{2}-\right.$ day $)$. This definition presumes that the material being leached is uniformly distributed through the matrix and that it enters solution by dissolution of the matrix material. This presumption is not strictly true because leach rates usually decrease with time of exposure to water and depend on the substance being leached. 
However, leach rates determined after long-exposure periods tend to be independent of time and less dependent on the substance being leached. ${ }^{5,6}$ To a first approximation it may be assumed, therefore, that leaching depends only on the dissolution of matrix material and that leaching occurs at a constant rate.

If the solidified waste is assumed to be in the form of cylinders of initial radius $r_{O}$ and of sufficient length that end effects can be ignored, the radius $r$ of the cylinder at time $T$ after immersion in water is given by the expression:

$$
\begin{aligned}
& r=r_{0}(1-\beta T) \\
& \beta=\frac{L}{\rho r_{0}}
\end{aligned}
$$

where

$$
\begin{aligned}
& \mathrm{L}=1 \text { each rate and } \\
& \rho=\text { density of the solid }
\end{aligned}
$$

The amount of activity in the environment, $\mathrm{N}_{e}$, at the time $T$ after immersion, caused by icaching from the cylinder is given by the expression:

$$
\mathrm{N}_{\mathrm{e}}=\mathrm{N}_{\mathrm{O}} 2 \beta \mathrm{T}\left(1-\frac{\beta \mathrm{T}}{2}\right) \mathrm{e}^{-\lambda T}
$$

where

$$
\begin{aligned}
N_{O} & =\text { the total activity originally in the cylinder and } \\
\lambda & =\text { decay constant of isotope involved. }
\end{aligned}
$$

The quantity $\beta^{-1}$ is the lifetime of the cylinder, i.e., the time at which $r$ goes to zero. The activity in the environment, $\mathrm{Ne}$, in equation (2) goes through a maximum at time $\mathrm{T}_{\max }$.

$$
\mathrm{T}_{\max }=\lambda^{-1}+\beta^{-1}-\sqrt{\lambda^{-2}+\beta^{-2}}
$$

For sufficiently large values of $\beta^{-1}, T_{\max }$ approaches $\lambda^{-1}$.

Table IV contains the relations between leach rates and quantities, calculated from the above equations, that are directly related to safety. The first column contains leach rates in $\mathrm{g} /\left(\mathrm{cm}^{2}\right.$-day $)$. The range shown covers the leach rates of solid forms produced by present technology. The second column contains the lifetime in years of a cylinder exposed to water continuously, assuming the density to be $2 \mathrm{~g} / \mathrm{cm}^{3}$ and the initial radius ro $=30 \mathrm{~cm}$ 
(2 $\mathrm{ft}$ in diameter). This is the size of waste form that might conveniently be made for SRP waste. Column 3 contains the maximum ${ }^{137} \mathrm{Cs}-{ }^{90} \mathrm{Sr}$ activity in $\mathrm{Ci}\left(\mathrm{N}_{\mathrm{e}}\right.$ at $\left.\mathrm{T}_{\max }\right)$ leached from cylinders of the above dimensions, assuming all the containers are breached, and the initial activity of the SRP waste is $4 \times 10^{8} \mathrm{Ci}$. For leach rates of $10^{-3} \mathrm{~g} /\left(\mathrm{cm}^{2}\right.$-day) or smaller, $\mathrm{T}_{\max }$ is about 40 years.

Column 4 contains the amount of ${ }^{137} \mathrm{Cs}-{ }^{90} \mathrm{Sr}$ activity leached if the waste were involved in an accident in which all the containers are breached and the contents exposed to water for 150 days.

Column 5 gives the time required to leach $1000 \mathrm{Ci}\left(500 \mathrm{Ci}\right.$ of ${ }^{90} \mathrm{Sr}$ and $500 \mathrm{Ci}$ of ${ }^{13^{7}} \mathrm{Cs}$ )* if all containers are breached and exposed to water. This is essentially the time available to operating personnel to take remedial action before the $1000 \mathrm{Ci}$ release would occur in the event of an accident resulting in the immersion of a11 waste containers.

TABLE IV. Relation Between Leach Rates and Quantities Directly Related to Safety

\begin{tabular}{|c|c|c|c|c|c|}
\hline $\begin{array}{l}\text { Leach Rate, } \\
\mathrm{g} /\left(\mathrm{cm}^{2}-d a y\right)\end{array}$ & $\begin{array}{l}B^{-1} \\
\text { Lifetime, } \\
\text { years } \\
\end{array}$ & $\begin{array}{l}\text { Maximum } \\
\text { Sr-Cs Activity } \\
\text { In the Environment, } \\
\text { Ci }\end{array}$ & $\begin{array}{l}\text { Sr-Cs Activity } \\
\text { Leached in } \\
150 \text { Days, Ci } \\
\end{array}$ & $\begin{array}{l}\text { Time to Leach } \\
1000 \mathrm{Ci}\end{array}$ & $\begin{array}{l}\text { Percent of } \\
\text { Containers } \\
\text { Breached to } \\
\text { Leach } 10^{3} \mathrm{Ci} \\
\text { in } 150 \text { Days }\end{array}$ \\
\hline 1 & 0.17 & $4.0 \times 10^{8}$ & $4 \times 10^{8}$ & $6.6 \mathrm{sec}$ & 0.0003 \\
\hline $10^{-1}$ & 1.7 & $3.8 \times 10^{8}$ & $2 \times 10^{8}$ & $66 \mathrm{sec}$ & 0.0006 \\
\hline $10^{-2}$ & 17 & $2.7 \times 10^{8}$ & $2 \times 10^{7}$ & $10 \mathrm{~min}$ & 0.005 \\
\hline $10^{-3}$ & $1.7 \times 10^{2}$ & $6.6 \times 10^{7}$ & $2 \times 10^{6}$ & $1.8 \mathrm{hr}$ & 0.05 \\
\hline $10^{-4}$ & $1.7 \times 10^{3}$ & $7.5 \times 10^{6}$ & $2 \times 10^{5}$ & $18 \mathrm{hr}$ & 0.5 \\
\hline $10^{-5}$ & $1.7 \times 10^{4}$ & $7.6 \times 10^{5}$ & $2 \times 10^{4}$ & 7.6 days & 5.0 \\
\hline $10^{-6}$ & $1.7 \times 10^{5}$ & $7.6 \times 10^{4}$ & $2 \times 10^{3}$ & 76 days & 50 \\
\hline $10^{-7}$ & $1.7 \times 10^{6}$ & $7.6 \times 10^{3}$ & $2 \times 10^{2}$ & $3.1 \mathrm{yr}$ & 100 \\
\hline $10^{-8}$ & $1.7 \times 10^{7}$ & $7.6 \times 10^{2}$ & $2 \times 10^{1}$ & $\infty$ & 100 \\
\hline
\end{tabular}

* $1000 \mathrm{Ci}$ was chosen as a release that would result in consequences significantly less than present guidelines for accident conditions. Based on calculations of Evans, Marter, and Reinig ${ }^{7}$ an estimated 1000-curie release would lead to a whole body dose of less than 0.2 rem to an individual in the most exposed population at Savannah, Georgia. This dose is less than $1 \%$ of the present 25 rem guidelines for accident situations. ${ }^{8}$ 
Column 6 contains the percentage of the containers that could be breached and exposed to water for 150 days before leaching $1000 \mathrm{Ci}$. These numbers relate the magnitude of an accident to the potential consequences.

With leach rates of $10^{-8} \mathrm{~g} /\left(\mathrm{cm}^{2}\right.$-day) or less, it is highly improbable that an accident will lead to serious consequences unless the waste forms are broken into small pieces. It therefore appears to be unprofitable to attempt to prepare less 10 chable forms.

With leach rates in the range from $10^{-8}$ to $10^{-6} \mathrm{~g} /\left(\mathrm{cm}^{2}\right.$-day), $t \therefore$ waste could survive severe accidents with 1 ittle consequence. For example, with a leach rate of $10^{-6} \mathrm{~g} /\left(\mathrm{cm}^{2}-\right.$ day $)$, all of the containers could be ruptured and all of the waste submerged in water for 76 days before $1000 \mathrm{Ci}$ of ${ }^{137} \mathrm{Cs}-{ }^{90} \mathrm{Sr}$ activity would be leached. This should be ample time to take corrective action.

Leach rates of $10^{-5}$ to $10^{-4} \mathrm{~g} /\left(\mathrm{cm}^{2}\right.$-day) provide protection against smaller accidents that have a higher probability. For example, at $10^{-4} \mathrm{~g} /\left(\mathrm{cm}^{2}\right.$-day $)$ all of the containers could be breached and the contents submerged for 18 hours before $1000 \mathrm{Ci}$ of activity would be leached, or $10 \%$ of the containers could be breached and the contents exposed to water for 7.6 days before $1000 \mathrm{Ci}$ would be leached.

\section{Chemical and Radiation Stability}

Good chemical and radiation stability are necessary if waste forms are to retain their original properties and if overpressurization of the container by radiolytic gas is to be prevented. The requirement for radiation stability is less stringent for SRP waste than for power reactor waste because of the lower power density of SRP waste. Solidified SRP waste will be required to survive an integrated dose of about $10^{9}$ rad not correcting for concentration or dilution during fixation.

\section{Mechanical Strength}

Mechanical ruggedness is desirable to reduce the probability of waste forms breaking into smaller pieces. Breakage would result in more difficult retrieval and increased leach rates because of increased surface area; also it could lead to airborne dispersion if fine powders were formed. Although mechanical ruggedness is primarily of importance during transfer, it is also important after the waste is in storage to lessen the consequences of accidents such as airplane crashes or earthquakes. Mechanical strength is a more important property for SRP wastes than is high thermal conductivity. 


\section{Corrosiveness to Containers}

Noncorrosiveness of waste to containers is necessary because integrity of the primary container is essential to the safety and feasibility of engineered storage. Corrosion rates will likely be lower with SRP wastes than with power reactor wastes because of the lower heat rate and thus lower temperature of SRP wastes.

Minimum Volume

Minimum volume is closely related to minimum cost and does not increase the safety of the stored waste. Actually, minimum volume wastes are more hazardous because of their high heat generation rate. A primary concern with high-level wastes from power reactors is the consequence of loss of cooling. A minimum volume waste with a power density of $100 \mathrm{w} / 1$ will heat at the rate of about $2000^{\circ} \mathrm{C} /$ day if not cooled; a more dilute waste, such as SRP waste with a power density of $0.008 \mathrm{w} / 1$, will heat at a maximum initial rate of about $60^{\circ} \mathrm{C} /$ year. The minimum volume waste would melt rapidly after cooling is lost; the more dilute waste would not.

\section{PROPERTIES OF POTENTIALLY USEFUL SOLID FORMS AND ASSOCIATED PROCESSES (From Literature)}

The properties of solid waste forms reported in the literature and relevent to the present discussion are shown in Table $V$. The various forms that might be applicable to SRP waste fall into three categories: calcines, glasses and ceramics, and intermediate-leve1 forms.

\section{Calcines}

Calcines are formed by simply removing water from the waste and perhaps thermally decomposing nitrates or converting to another anhydrous salt. The product that could be produced from SRP wastes would be mainly $\mathrm{NaNO}_{3}, \mathrm{Na}_{2} \mathrm{O}, \mathrm{Na}_{2} \mathrm{SO}_{4}$, or $\mathrm{NaAlO}_{2}$. Of these products, only $\mathrm{NaNO}_{3}$ with its low melting point could be converted easily into a monolith; the others would probably exist as granules. All calcines that could be produced from SRP waste are characterized by high leachability.

Calcines are produced by pot calcination, spray calcination, or by the fluidized bed method. ${ }^{2}$ The first two methods appear to be completely compatible with SRP supernates. However, there may be problems with mercury during processing of SRP sludges, because all mercury compounds decompose above $400^{\circ} \mathrm{C}$; volatilization of metallic mercury would require special off-gas systems. ${ }^{2}$ 
TABLE V. Properties of Various Solid Waste Forms

\begin{tabular}{|c|c|c|c|c|c|}
\hline Whe of solid & Form & $\begin{array}{l}\text { Leachability, } \\
\mathrm{g} /\left(\mathrm{cm}^{2}-d a y\right)\end{array}$ & Hardness & Friability & Reference \\
\hline \multicolumn{6}{|l|}{ Calcines } \\
\hline $\begin{array}{l}\text { Low temperature melt } \\
\mathrm{NaNO}_{3}-\mathrm{NaOH}\end{array}$ & $\begin{array}{l}\text { Monolith } \\
\text { Crystals }\end{array}$ & 1 to $10^{-1}$ & Moderate & Moderately tough & \\
\hline $\begin{array}{l}\mathrm{Pot} \text { calcine } \\
\mathrm{Na}_{2} \mathrm{O}\end{array}$ & $\begin{array}{l}\text { Calcine Cake } \\
\text { Scale }\end{array}$ & 1 to $10^{-1}$ & Soft & Crumbly & 2,4 \\
\hline $\begin{array}{l}\text { Fluid bed calcine } \\
\mathrm{Na}_{2} \mathrm{SO}\end{array}$ & Granular & 1 to $10^{-1}$ & Moderate & Moderate & 2 \\
\hline \multicolumn{6}{|l|}{ Glasses and Ceramics } \\
\hline WSEP phosphate glass & $\begin{array}{l}\text { Monolith } \\
\text { Glass }\end{array}$ & $\begin{array}{l}6 \times 10^{-7} \text { to } \\
4 \times 10^{-6}\end{array}$ & Hard & Brittle & 2,4 \\
\hline $\begin{array}{l}\text { WSEP phosphate glass } \\
\text { (devitrified) }\end{array}$ & $\begin{array}{l}\text { Monolith } \\
\text { Crystals }\end{array}$ & $\begin{array}{lll}3 & \times 10^{-4} \\
5 & \times & 10^{-3}\end{array}$ to & Hard & Brittle & 2,4 \\
\hline WSEP phosphate ceramic & $\begin{array}{l}\text { Monolith } \\
\text { Microcrystalline }\end{array}$ & $\begin{array}{l}6 \times 10^{-5} \\
8 \times 10^{-3}\end{array}$ & Hard & Tough & 2,4 \\
\hline WSEP horosilicate glass & $\begin{array}{l}\text { Monolith } \\
\text { Glass }\end{array}$ & $\begin{array}{l}9 \times 10^{-6} \\
5 \times 10^{-5}\end{array}$ & Hard & very brittle & 4 \\
\hline $\begin{array}{l}\text { French borosilicate } \\
\text { glass }\end{array}$ & $\begin{array}{l}\text { Monolith } \\
\text { Glass }\end{array}$ & $\begin{array}{l}1 \times 10^{-7} \\
3 \times 10^{-7}\end{array}$ & ? & $?$ & 9 \\
\hline $\begin{array}{l}\text { Fingal phosphosilicate } \\
\text { glass }\end{array}$ & $\begin{array}{l}\text { Monolith } \\
\text { Glass }\end{array}$ & $\begin{array}{lll}3 \times 10^{-7} \\
1 \times 10^{-6}\end{array}$ & Hard & Brittle & 5,10 \\
\hline $\begin{array}{l}\text { Fingal phosphosilicato } \\
\text { glass (Devitrified) }\end{array}$ & Mono?itr & $\begin{array}{lll}2 & \times 20^{-6} \\
1 & \times 10^{-5}\end{array}$ & t!ard & Brittle & 5,10 \\
\hline $\begin{array}{l}\text { Canadian alumino } \\
\text { silicate } \\
\text { nephelene-syenite- } \\
\text { CaO glass }\end{array}$ & Monolith & $\begin{array}{lll}3 \times 10^{-8} & \text { to } \\
2 \times & 10^{-7}\end{array}$ & Hard & Brittle & 11 \\
\hline $\begin{array}{r}\text { Thermite alumino } \\
\text { silicate glass }\end{array}$ & Monolith & $\begin{array}{l}3 \times 10^{-8} \\
4 \times 10^{-7}\end{array}$ & Hard & $?$ & 12 \\
\hline $\begin{array}{l}\text { ARIICO thermalt } \\
\text { alumino silicate glass }\end{array}$ & Monolith & $\begin{array}{l}1 \times 10^{-7} \text { to } \\
2 \times 10^{-7}\end{array}$ & Hard & ? & 13 \\
\hline \multicolumn{6}{|l|}{ Intermediate-Level Forms } \\
\hline Aspha1t (Bitumen) & Monolith & $\begin{array}{l}1 \times 10^{-4} \\
3 \times 10^{-4} a^{\text {to }}\end{array}$ & Moderate & Tough & 14,15 \\
\hline Geperi. & Monolith & $\begin{array}{l}10^{-1} \text { to } \\
2 \times 10^{-9}\end{array}$ & Hard & Tough & 16,17 \\
\hline
\end{tabular}

a. Asphalt incorporating 20 to 40 wt $\% \mathrm{NaNO}_{3}$.

Fluidized bed calcination is not compatible with wastes containing sodium nitrate because the low melting point of that salt causes particles in the bed to stick together. This process could be used if the waste were converted to the sulfate or aluminate. 
Calcination methods, as do all high-temperature procedures, require elaborate off-gas treatment systems because of volatile ruthenium oxides and entrained matter. A solid waste form might be produced by simply evaporating the water and heating to melt sodium nitrate at a sufficiently low temperature to avoid ruthenium volatilization.

\section{Giasses and Ceramics}

Glasses and ceramics are produced by adding glass-forming agents to the waste and heating to form a melt, which is subsequently cast as a monolith and cooled. Glasses are generally characterized by low leachability, high thermal conductivity, hardness, and high friability.

There are three glasses that have been developed for waste fixation: phosphate, borosilicate, and aluminosilicate. Leachability generally decreases in the listed order; however, there are large variations within each class because of the wide variation of chemical composition possible. In general, low leachabilities are associated with high melting points.

A.1 I glasses are slbject to d phenomerton known as devitrification (probably crystallization), which generally causes an increase in leachability. This problem is particularly severe in phosphate glasses because leachability can increase a thousandfold following devitrification. ${ }^{6}$ Devitrification usually occurs when glasses are held at high temperature for prolonged periods. Since this is the usual condition for high-level wastes from power reactors, devitrification is almost certain to occur. A1though SRP wastes would have much lower temperatures, it must be presumed that they would also devitrify in the very long storage periods required of them.

Glasses are produced by a variety of methods $2,3,9,18,19$ that may differ in detail, but consist mainly of adding glass-forming agents to the waste before or after evaporation of the water and heating to a sufficiently high temperature to form a melt that is cooled to a glass. The process may be continuous as in the spray melt process or batch as in the pot glass process. The two products that have been studied in detail are phosphate and borosilicate glasses; aluminosilicate glasses are produced by methods ${ }^{12,13}$ that have not been developed sufficiently to be of use at present.

Direct conversion of SRP waste to either phosphate or borosilicate glass would be difficult because of the presence of mercury, sulfate, and fluoride. ${ }^{2},{ }^{3}$ Mercury may require a special off-gas system, and sulfate and fluoride may cause excessive corrosion of the process equipment. In the case of boro- 
silicate glasses, sulfates separate from the melt as a phase that floats; such a phase is highly leachable after the glass has cooled.

\section{Intermediate-Leve1 Forms}

Forms for intermediate-level wastes are included in the present discussion because these forms may be applicable to SRP wastes. As already concluded, some of the properties required for high-level wastes (high thermal conductivity, and the ability to withstand high temperature ard radiation doses) are not necessary for SRP waste. Thus, solid forms for intermediate-level wastes may be able to withstand the temperatures and radiation fields likely to be produced by SRP wastes. Although a large number of solidification schemes have been proposed for intermediate-level waste solidification, recent work has concentrated on the use of asphalt (bitumen) and cement.

\section{Asphalt}

Asphalt is currently used in Europe $15,20,21$ to fix lowand intermediate-level wastes, incorporating sludges as well as sodium nitrate from evaporator concentrates. Up to $60 \%$ of soluble salts $\left(\mathrm{NaNO}_{3}+\mathrm{Na}_{2} \mathrm{CO}_{3}\right)$ have been incorporated into asphalt. ${ }^{15}$ A typical asphalt containing about $20 \%$ soluble salts has a leachability of about $5 \times 10^{-4} \mathrm{~g} /\left(\mathrm{cm}^{2}\right.$-day $) ; 14,15$ those containing more soluble salts are more leachable. Those that contain less than $1 \%$ soluble matter, however, are "completely" resistant to leaching. ${ }^{15}$

While incorporation of up to $60 \% \mathrm{NaNO}_{3}$ into asphalt would seem to yield an explosive mixture, this does not appear to be the case. Although incorporation of 40 to $60 \% \mathrm{NaNO}_{3}$ into asphalt increases the flammability (samples spontaneously ignite at $330^{\circ} \mathrm{C}$, compared to $450^{\circ} \mathrm{C}$ for untreated asphalt), the mixture will not detonate. ${ }^{14}$ There are indications, however, that $\mathrm{MnO}_{2}-\mathrm{NaNO}_{3}$ combinations will lower the temperature of spontaneous ignition dangerous $1 \mathrm{y} .{ }^{15}$

Russian workers ${ }^{20}$ have studied a procedure in which radionuclides are absorbed on vermiculite or zeolite, which is then incorporated into bitumen. They report that very little activity is leached by water, but do not give values for leachability. 
From a production point of view asphalt appears to be quite compatible with SRP wastes. Sludges and even sodium nitratebearing wastes have successfully been incorporated into asphalt. 14,15,21,22 In processing, the waste is mixed with emulsified asphalt and evaporated in a wiped film evaporator at about $160^{\circ} \mathrm{C}$. The product containing molten asphalt and anhydrous sludges and salts is then drained into a suitable container where it solidifies. There appears to have been little difficulty with the process, although one fire was reported ${ }^{15}$ when sodium nitrate and manganese dioxide were simultaneously incorporated into asphalt in a laboratory test. Problems of mercury volatilization may occur, but have not been reported.

\section{Cement}

Cement has been studied extensively for the fixation of radioactive wastes. $15,16,17,22,23$ It has been or is being used at several locations for fixing low- and intermediate-level wastes.14,18-21 With few exceptions, solidification with cement consists simply of mixing liquid wastes containing large concentrations of soluble salts with cement and allowing the mixture to set. These salt-bearing cements are naturally highly leachable, particularly for highly soluble radionuclides such as ${ }^{137} \mathrm{Cs}$. Russian workers ${ }^{17,24}$ have measured leachability to be between $10^{-1}$ and $10^{-2} \mathrm{~g} /\left(\mathrm{cm}^{2}\right.$-day). B1 anco, ${ }^{23}$ by inference, reported leachabilities for sodium and cesium between $7.5 \times 10^{-3}$ and $1.5 \times 10^{-2}$ $\mathrm{g} /\left(\mathrm{cm}^{2}\right.$-day). (He actually reported that the leachability of aspha1t was $1.5 \times 10^{-4} \mathrm{~g} /\left(\mathrm{cm}^{2}\right.$-day) and that cement containing the same amount of waste was 50 to 100 times more leachable.) 0ther workers $25-28$ reported that from $4.8 \%$ to $15 \%$ of the activity was leached from salt-bearing cemented wastes in 15 to 42 days, but they did not calculate leachabilities.

The leachability of cement containing no soluble salts is much lower than that of cement containing salts. French workers ${ }^{29}$ investigated the leaching of radioactive sludges incorporated in cement and reported data from which were calculated average leachabilities of $2 \times 10^{-4}$ to $4 \times 10^{-5} \mathrm{~g} /\left(\mathrm{cm}^{2}-\right.$ day $)$ over a period of 45 days. Their data suggest that these rates will decrease substantially with time. Italian workers ${ }^{30}$ reported data on leaching of mixed fission products from different types of cement, from which leach rates were calculated. Portland cement gave initial leachabilities of $1.7 \times 10^{-3} \mathrm{~g} /\left(\mathrm{cm}^{2}\right.$-day $)$, which dropped to $4.6 \times 10^{-5} \mathrm{~g} /\left(\mathrm{cm}^{2}\right.$-day $)$ after 119 days immersion in water. pozzolanic cement gave an initial rate of $7 \times 10^{-4} \mathrm{~g} /\left(\mathrm{cm}^{2}-\right.$ day $)$, which dropped to $2.6 \times 10^{-6} \mathrm{~g} /\left(\mathrm{cm}^{2}\right.$-day $)$ after 119 days. 
Leach rates determined from leaching of actinides are smaller than those determined with mixed fission products. Workers at Los Alamos 16,31 incorporated wastes containing plutonium and americium as well as soluble salts in cement mortars and studied their leaching properties. Average leach rates calculated from these data are $1.1 \times 10^{-7} \mathrm{~g} /\left(\mathrm{cm}^{2}\right.$-day $)$ during the first year. The instantaneous leach rate after about a year was $2 \times 10^{-9} \mathrm{~g} /\left(\mathrm{cm}^{2}\right.$-day $)$. These values are probably smaller than the actual dissolution rate of cement because of adsorption of plutonium and americium on cement surfaces. The dissolution rate of concrete in the SRP disassembly basin is estimated to be $4.7 \times 10^{-5} \mathrm{lb} /\left(\mathrm{ft}^{2}-\mathrm{day}\right)$. or $2.3 \times 10^{-5} \mathrm{~g} /\left(\mathrm{cm}^{2}\right.$-day $)$. The preceeding data indicate that, under some conditions, the leach rate of cement can be as low as that of glass.

Portland cement is thermally stable up to $300^{\circ} \mathrm{C}$; prolonged heating at $500^{\circ} \mathrm{C}$, however, causes a $50 \%$ or more loss in compressive strength, and complete failure occurs at $900^{\circ} \mathrm{C} .{ }^{32}$ It is highly resistant to gamma radiation; reactor shields composed of Portland cement showed a loss of compressive strength of only one half after an exposure of $3 \times 10^{18}$ roentgens. ${ }^{33}$

From a production standpoint, cement is probably the mostconvenient material with which to solidify waste; all that is required is that the material to be solidified is mixed with cement and water and the mixture is cast into the desired monolithic shape and allowed to set. Because cement mixing is a low-temperature process, there should be none of the off-gas treatment problems or corrosion problems associated with the high-temperature process for making glass.

\section{EVALUATION OF PRODUCT FORMS FOR SRP WASTE}

In this section, the waste forms previously discussed will be evaluated for application to SRP wastes. Two different bases will be used for the evaluation. First, it will be assumed that the sludge and supernate will be mixed together and converted to a solid form. In the second case, it will be assumed that the sludge and supernate are segregated and that the supernate is further decontaminated to remove the bulk of the cesium.

\section{Combined Wastes}

Calcines have the poorest properties of the solid waste forms considered. They are highly leachable, porous (except for the $\mathrm{NaNO}_{3}$ low-temperature solid), and friable so that they provide no barrier to dispersion of activity via water or air. McElroy et a1. ${ }^{34}$ showed that $25 \%$ of the cesium in a calcine 
made by the pot calcination process was leached within a week. of the calcines, the low-temperature solidification product $\left(\mathrm{NaNO}_{3}\right)$ is probably the best (assuming radiation stability is adequate) because it can be cast into monoliths.

Calcines can be made from SRP wastes by a variety of processes. Large and expensive off-gas systems will be required to remove volatilized ruthenium and particulate matter. If the high-temperature calcination processes are used to convert SRP sodium nitrate wastes into sodium oxide, sulfate, or aluminate, means will be required to dispose of the tons of potentially contaminated nitric acid or oxides of nitrogen produced. Mercury in SRP sludges might require special of $f$-gas systems.

Phosphate glass and ceramic are products of only moderate quality. The leach rate of the ceramic prepared by the spray melt process is initially high $\left[10^{-3}\right.$ to $10^{-4} \mathrm{~g} /\left(\mathrm{cm}^{2}-\right.$ day $\left.)\right]$; that of the glass, while initially low, becomes high when the glass devitrifies. These materials are superior to calcines because of their lower leach rates and because they form monolithic solids.

The phosphate products can be made with wastes containing sulfate, although its presence causes some problems. The introducticn of apprepriate chamicals can reduce the volatilization of sulfate in the spray melt process to less than $5 \%$, but this residual sulfate as well as the fluoride in SRP waste would cause corrosion in the off-gas system; the mercury would require special design to avoid pluggage. ${ }^{34}$

Borosilicate glass is one of the best products that has been produced by well-developed technology. The leach rate is very low $\left[10^{-6}\right.$ to $\left.10^{-7} \mathrm{~g} /\left(\mathrm{cm}^{2}-\mathrm{day}\right)\right]$, although the material is very fragile and shatters easily. Borosilicate glass unfortunately cannot be made from wastes containing sulfate because of the formation of a separate phase that floats to the top of the melt and is very leachable. Even if adequate borosilicate glass could be made from SRP wastes, the mercury, fluoride, and ruthenium would present the same process problems as phosphate glass.

Aluminosilicates are probably the most insoluble materials that can be produced from waste. Unfortunately, the technology for their production has not been developed to the point where their compatibility with SRP waste can be adequately assessed. Since aluminosilicates melt at higher temperatures than the other glasses, it is probable that the same volatility problems would occur as with other high-temperature processes. 
Asphalt can easily be incorporated into SRP waste to produce a product with a leach rate of about $10^{-4} \mathrm{~g} /\left(\mathrm{cm}^{2}\right.$-day), which might be adequate. However, flammability of asphalt may make its use unacceptable to the public even though it is presently used in Europe to fix intermediate-level waste. It is also doubtful that asphalt could withstand the radiation dose $\left(10^{9}\right.$ to $10^{10}$ rads $)$ expected from SRP wastes.

Cement has adequate radiation stability, and its thermal stability is also adequate provided that the temperature does not greatiy exceed $300^{\circ} \mathrm{C}$. The presence of large amounts of soluble salts, however, renders cement physically weak, highly leachable, and therefore unsuitable for fixation of combined wastes.

There does not appear to be any entirely satisfactory process available to solidify combined SRP wastes. Mercury in the sludge would pose problems in all of the high-temperature processes, while sulfate and fluoride in the supernate would interfere with the glass-making processes because of corrosion or incompatibility with the product. Asphalt, which is already flammable, is rendered more so by the nitrates in the supernate: Cement is rendered too leachable by these salts.

\section{Segregated Waste}

Interference with most waste solidification schemes by the large volume of soluble salts in SRP supernate prompted consideration of alternatives involving partial segregation of the wastes. The simplest procedure is to separate the sludge from the supernate. This isolates much of the toxicity hazard (a11 of the ${ }^{90} \mathrm{Sr}$ and ${ }^{239} \mathrm{Pu}$ ) in a relatively low volume and in a material of low solubility. Half of the activity (all of the ${ }^{1{ }^{7}} \mathrm{Cs}$ ) will remain in the supernate. However, the cesium can be removed from the salt-bearing supernate by sorption on ion exchange resin or zeolite, ${ }^{34,35}$ and can be stored on zeolite. Thus, there will be three waste fractions: the sludge containing almost all of the strontium and the plutonium, zeolite containing almost all of the cesium, and the supernate containing the soluble salts but little long-lived radionuclides (the principal radionuclide remaining in the supernate will be ${ }^{106} \mathrm{Ru}$ ).

Because the above procedures concentrate the bulk of the activity in insoluble solids, fixation should be simpler. Because zeolite is an aluminosilicate, it should be compatible with aluminosilicate, borosilicate, and perhaps phosphate glasses. It could also be incorporated as an aggregate in concrete. The sludge, however, would contain mercury and perhaps some sulfate, which present problems in high-temperature processes. 
Because soluble salts are absent, sludge and zeolite could be incorporated into concrete to obtain a material with leach rates between $10^{-5}$ and $10^{-6} \mathrm{~g} /\left(\mathrm{cm}^{2}\right.$-day). These rates are nearly as low as any obtained with glass, and much lower than some (phosphate glasses for example). Concrete mixing poses none of the production problems (mercury and ruthenium volatilization) of the high-temperature processes. Furthermore, concrete is physically strong and has proved its durability in Roman buildings and marine works that have lasted nearly two millennia. ${ }^{32}$

Sludge and zeolite could also be incorporated into asphalt, but fire hazards and uncertain radiation stability would seem to make asphalt as unacceptable for segregated waste as for sa1t-bearing waste.

A summary of the properties of the various solid waste forms and the evaluation of each are given in Table VI. 
TABLE V1. Evaluation of Product Forms for SRP Waste ${ }^{a}$

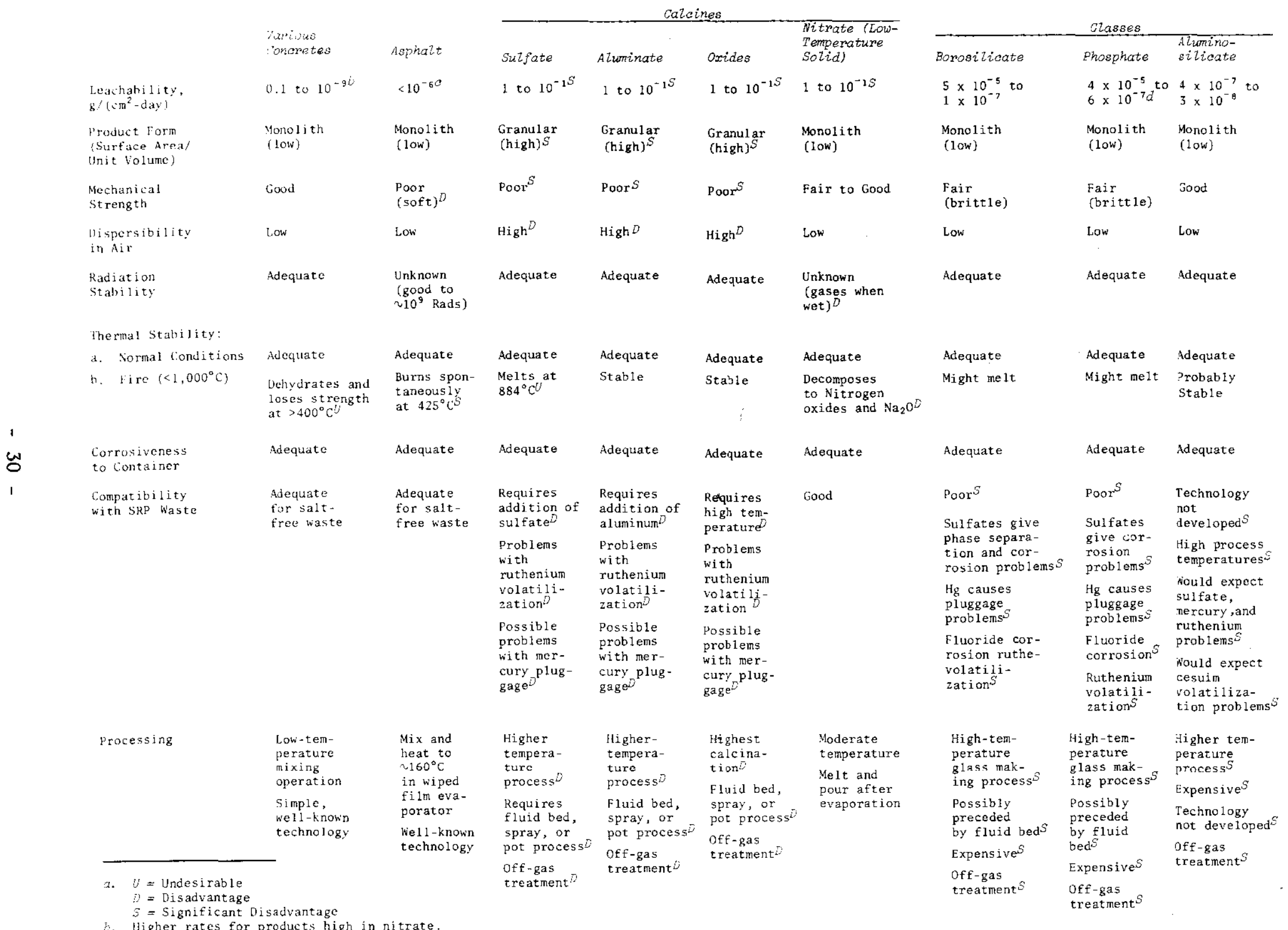




\section{APPENDIX}

\section{EQUATIONS FOR LEACHING}

\section{GENERAL EQUATIONS}

A solid is assumed to leach ideally if in a given time period a uniform layer of solid dissolves from the surface, and any substance dispersed in the solid also enters solution in proportion to its concentration in the solid and the amount of solid dissolved.

The time rate of loss of mass of a leaching solid is given by

$$
\frac{\mathrm{dm}}{\mathrm{dt}}=-\mathrm{LA}
$$

where

$$
\begin{aligned}
& \mathrm{m}=\text { the mass in grams } \\
& \mathrm{t}=\text { the time in days } \\
& \mathrm{A}=\text { the surface area in } \mathrm{cm}^{2} \\
& \mathrm{~L}=\text { the leachability in } \mathrm{g} /\left(\mathrm{cm}^{2}\right. \text {-day) }
\end{aligned}
$$

The rate of increase of volume of the solid per unit time is then given by

$$
\frac{\mathrm{d} v}{\mathrm{dt}}=\frac{-\mathrm{LA}}{\rho}
$$

where

$$
\begin{aligned}
& \mathrm{v}=\text { the volume in } \mathrm{cm}^{3} \\
& \rho=\text { the density in } \mathrm{g} / \mathrm{cm}^{3} .
\end{aligned}
$$

Since the solid dissolves uniform $1 y$, the volume dissolved in a short period can be represented as the product of the surface area and a uniform displacement vector, $X$, normal to the surface.

$$
\mathrm{V}=\mathrm{AX}
$$

The penetration rate, $\frac{d x}{d t}$, can be obtained by substituting Equation 3 into Equation 2. 


$$
\frac{\mathrm{dx}}{\mathrm{dt}}=\frac{-\mathrm{L}}{\rho} \mathrm{cm} / \mathrm{day}
$$

One way in which leach rates are measured is to incorporate a radioactive substance into the solid. The fraction $f$ of the activity leached in a given time is measured, and the leachability is calculated as follows:

The increment of volume $\delta \mathrm{V}$ dissolving in a time interval $\delta \mathrm{t}$ is obtained from Equation 2.

$$
\frac{\delta V}{\delta t}=\frac{L A}{\rho}
$$

If Equation 5 is divided by the initial volume of the solid, $V$

$$
\frac{1}{V} \frac{\delta V}{\delta t}=\frac{L A}{V \rho}
$$

But $\frac{\delta V}{V}=f$, the fraction of the volume dissolved, which is assumed to be the same as the fraction of the activity dissolved. The leachability can then be calculated:

$$
L=\frac{f V \rho}{(\delta t) \dot{A}}
$$

\section{LEACHING OF WASTE CYLINDERS}

Consider a cylinder of initial radius $r_{0}$ and of sufficient length that the area of the ends (and thus dissolution of the ends) can be ignored compared to the cylindrical surface. Since the radius, $r$, of a cylinder is normal to the surface, Equation 4 becomes:

$$
\frac{d r}{d t}=\frac{-L}{\rho}
$$

When Equation 8 is integrated, subject to the initial conditions that $r=r_{0}$ at $t=0$, the following is obtained:

$$
\text { where } \quad \begin{aligned}
r & =r_{0}-\frac{L}{\rho} t \\
\text { or } \quad r & =r_{0}(1-\beta t) \\
\beta & =\frac{L}{\rho r_{O}}
\end{aligned}
$$

Since $r=0$ when $t=\beta^{-1}, \beta^{-1}$ is the life of the cylinders. 


\section{ACTIVITY IN THE ENVIRONMENT DUE TO LEACHING}

Consider a cylinder of initial radius $r_{0}$, density $\rho$, and leachability $\mathrm{L}$, and which initially contains $\mathrm{N}_{O}$ curies of activity. Let the cylinder be placed in contact with water at time, $t=0$. The rate at which activity accumulates in the environment is the difference between the rate at which it leaches from the cylinder into the environment and the rate at which it decays. $t$, then

If $\mathrm{N}_{e}$ is the amount of leached activity accumulated at time

$$
\frac{\mathrm{dNe}}{\mathrm{dt}}=\mathrm{C} \frac{\mathrm{dv}}{\mathrm{dt}}-\lambda \mathrm{Ne}
$$

where

$$
\begin{aligned}
\lambda= & \text { decay constant } \\
\mathrm{C}= & \text { the concentration of activity in the cylinder in } \\
& \text { curies per unit volume at any time, } \\
\frac{\mathrm{dv}}{\mathrm{d} t}= & \text { the rate of decrease of the volume of the cylinder }
\end{aligned}
$$

Since

$$
\begin{aligned}
& V=\pi r^{2} h \\
& \frac{d v}{d t}=2 \pi h r \frac{d r}{d t}
\end{aligned}
$$

But from Equation 9,

$$
r=r_{0}(1-\beta t)
$$

Differentation of Equation 9 and substitution into Equation 13 gives,

$$
\frac{d v}{d t}=2 \pi r_{o}{ }^{2} h \beta(1-\beta t)
$$

Therefore

$$
\frac{d v}{d t}=2 v_{o} \beta(1-\beta t)
$$

Substitution into Equation 11 yields

$$
\begin{array}{ll} 
& \frac{\mathrm{dN}}{\mathrm{dt}}=\mathrm{C} 2 \mathrm{~V}_{\mathrm{O}} \beta(1-\beta \mathrm{t})-\lambda \mathrm{N}_{\mathrm{e}} \\
\text { But } & \mathrm{C}=\frac{\mathrm{N}_{\mathrm{O}}}{\mathrm{V}_{\mathrm{O}}} \exp (-\lambda t)
\end{array}
$$


Therefore $\quad \frac{d N_{e}}{d t}=2 N_{o} \beta(1-\beta t) \exp (-\lambda t)-\lambda N_{e}$

Equation 17 can be integrated with the initial conditions, $\mathrm{N}_{e}=0$ when $\mathrm{t}=0$, to give

$$
N_{e}=2 N_{o} \beta t\left(1-\frac{\beta t}{2}\right) \exp (-\lambda t)
$$

CALCULATION OF THE TIME, $T_{\max }$, AT WHICH $\mathrm{N}_{\mathrm{e}}$ IS MAXIMUM

If Equation 18 is substituted into 17 and $\mathrm{dN}_{\mathrm{e}} / \mathrm{dt}=0$

$$
\frac{d N_{e}}{d t}=2 N_{o} \beta \exp \left(-\lambda t_{\max }\right)\left[1-\beta t_{\max }-\lambda\left(t_{\max }-\frac{\beta}{2} t^{2}{ }_{\max }\right)\right]=0
$$$$
\frac{\beta \lambda}{2} t^{2} \max (\beta+\lambda)+1=0
$$

$$
t_{\max }=\lambda^{-1}+\beta^{-1}-\sqrt{\lambda^{-2}+\beta^{-2}}
$$

The positive root of Equation 19 is ignored because it occurs at times larger than $\beta^{-1}$, which is the lifetime of the cylinder. 


\section{REFERENCES}

1. An Evaluation of the Concept of Storing Radioactive Wastes in Bedrock Below the Savannah River Plant. Report by the Committee on Radioactive Waste Management, National Academy of Sciences, U. S. Government Printing Office, Washington, D. C. (1972).

2. K. J. Schneider. "Solidification and Disposal of High-Level Radioactive Wastes in the United States." React. Tech 13, 387 (1970).

3. J. L. McElroy, A. G. Blasewitz, and K. J. Schneider. "Status of the Waste Solidification Demonstration Program." Nucl. Tech. 12, 69 (1971).

4. H. S. Carslaw and J. C. Jaeger. Conduction of Heat in Solids. 2nd ed, p. 191, C1arendon Press, Oxford (1959).

5. J. R. Grover, M. N. Elliott, and A. D. Jones."Long Term Examination of Glasses for the Fingal Process." Proceedings of the Symposium on the Solidification and Long-Term Storage of Highly Radioactive Wastes, February 14-18, 1966, Richland, Washington. JSA.EC Repcrt CCNF-660208, $r$. 585, JSAEC Division of Technical Information Extension, Oak Ridge, Tennessee (1966).

6. J. E. Mendel and J. L. McElroy. Waste Solidification Program, Volume 10, Evaluation of Solidified Waste Products. USAEC Report BNWL-1666, Pacific Northwest Laboratories, Battelle Memorial Institute, Rich1and, Washington (1972).

7. A. G. Evans, W. L. Marter, and W. C. Reinig. "Guides Limiting the Release of Radionuclides by the Savannah River Plant." Health Physics 15, 57 (1968).

8. U. S. Code of Federal Regulations, Title 10, Part 100, "Reactor Site Criteria."

9. R. Bonniaud. "Survey of the Studies Conducted in France on the Solidification of Concentrated Fission Product Solutions." Proceedings of the Symposium on the Solidification and Long-Term Storage of Highly Radioactive Wastes, February 14-16, 1966, Richland, Washington. USAEC Report CONF-660208, p. 120, USAEC Division of Technical Information Extension, Oak Ridge, Tennessee (1966). 
10. J. R. Grover and D. Walmsley. British Report AERE-R-5583 (1968).

11. A. R. Bancroft and J. D. Gamble. Initiation of a Fiezd Burial Test of the Disposal of Fission Products Incorporated into Glass. Canadian Report AECL-718, Atomic Energy of Canada Ltd., Chalk River, Ontario (1958).

12. M. L. Spector, E. Suriani, and G. L. Stukenbroker. "Thermite Process for the Fixation of High Level Radioactive Waste." Ind. Eng. Chem. Proc. Design Devel. 7, 117 (1968).

13. L. Brownel1, M. J. Kipfer, R. E. Isaacson, and W. W. Schulz. The Thermalt Process for Immobilization of Radioactive Wastes. ARH-2059, p. 14, Atlantic Richfield Hanford Co., Richland, Washington (1971).

14. C. L. Fitzgerald, H. W. Godbee, and R. E. B1anco. "The Feasibility of Incorporating Radioactive Wastes in Asphalt or Polyethylene." Nucl. Appl. Tech. 9, 821 (1970).

15. W. Bahr, W. Hempelmann, H. Krause, and O. Nèntwich. "Experience in the Treatment of Low- and Intermediate-Level Radioactive Wastes in the Nuclear Research Certre, Kar1srihe." Nanagement of Low- and Intermediate-Level Radioactive Wastes, Proceedings of a Symposium, Aix-En-Provence, Sept. 7-11, 1970, p. 461, International Atomic Energy Agency, Vienna (1970).

16. L. A. Emelity and C. W. Christenson. "Replacement of an old Treatment P1ant-A Design Based on Experiences." Management of Low- and Intermediate-Level Radioactive Wastes, Proceedings of a Symposium, Aix-En-Provence; Sept. 7-11, 1970, p. 609, International Atomic Energy Agency, Vienna (1970).

17. A. I. Nazarova, V. V. Kulichenko, F. S. Dukhovich, O. I. Valkova, M. V. Bayarinova, I. A. Sobalev, L. M. Khomchik, Yu. M. Bazhenov. Eixation of Radioactive Wastes in Cement. STIPUB - 116, p. 779 (in Russian) (1967) (Nuclear Science Abstracts, Vol. 21, No. 1, Abstract 270).

18. U. L. Upton and G. C. Weth. "Fixation of High-Level Radioactive Wastes in Phosphate Glass." Proceedings of the Symposium on the Solidification and Long-Term Storage of Highly Radioactive Wastes, February 14-16, 1966, Richland, Washington. USAEC Report CONF-660208, p. 144, USAEC Division of Technical Information Extension, Oak Ridge, Tennessee (1966). 
19. J. R. Grover, W. H. Hardwich, R. Gayler, and M. H. Delue. "The Fingal Process." Proceedings of the Symposium on the Solidification and Long-Term Storage of Highly Radioactive Wastes, February 14-16, 1966, Richland, Washington. USAEC Report CONF-660208, p. 427, USAEC Division of Technical Information Extension, Oak Ridge, Tennessee (1966).

20. K. Daiev, et a1. "Immobilization of Radioactive Wastes Attached to Natural Sorbents in Bitumen Moulds." Management of Low- and Intermediate-Level Radioactive Wastes, Proceedings of a Symposium Aix-En-Provence, Sept. 7-11, 1970, p. 739, International Atomic Energy Agency, Vienna (1970).

21. G. Lifillatre and R. Andicat. "Les Procedes Industriels d'Enrobage Par le Betume des Concentrats Liquides de Traitement Radioactif et le Stockage des Enrabes." Management of Lowand Intermediate-Level Radioactive Wastes, Proceedings of a Symposium, Aix-En-Provence, Sept.7-11, 1970, p. 383, International Atomic Energy Agency, Vienna (1970).

22. W. delaguna, T. Tamura, H. O. Weeren, E. G. Struxness, W. C. McClain, and R. C. Sexton. Engineering Development of Hydraulic Fracturing as a Method for Permanent Disposal of riciioacivive wastes. USAEC Report ORNL-4259, Oak Ridge National Laboratory, Oak Ridge, Tennessee (1968).

23. R. E. B1anco, et a1. "Recent Development in Treating Lowand Intermediate-Level Waste in the United States of America." Practices in the Treatment of Low- and Intermediate-Level Radioactive Waste, Proceedings of a Symposium, Vienna, Dec.6-10, 1965, p. 829, International Atomic Energy Agency, Vienna (1966).

24. V. V. Kulichenko, et al. "Fixation of Radioactive Waste in Cement." Practices in the Treatment of Low- and IntermediateLevel Radioactive Wastes, Proceedings of a Symposium, Vienna, Dec. 6-10, 1965, p. 779, International Atomic Energy Agency, Vienna (1966).

25. Disposal of Radioactive Wastes in Cement. USAEC Report KLX-1377, Vitro Corp. of America, New York (1952).

26. J. A. Kaufman and N. B. Garden. A Method for the Solidification of Aqueous Liquid Wastes. USAEC Report UCRL-8684, Lawrence Radiation Laboratory, Berkeley, California (1959). 
27. R. R. Halcomb. Solidification of Ion-Exchange Resin with Portland Cement for Radioactive Waste Disposal. USAEC Report ORNL-2899, Oak Ridge National Laboratory, Oak Ridge, Tennessee (1960).

28. J. M. White and G. Lahaier. Disposal of Moderately Radioactive Solutions in Cement Mortar. Canadian Report AECL1085, Atomic Energy of Canada, Ltd., Chalk River, Ontario (1960).

29. R. Bonniand and P. Choen. "Etude de 1a Solidification des Boues Radioactives." Energie Nucleare 2, 22 (1960).

30. E. Lazzarine, G. Tognan, A. Facchini, P. Geronotopulos, and G. Valerio. "On the Fixation of High1y Radioactive Wastes in Cement." Ind. Ital. Cement 33, 45 (1963) (ORNL-tr-144).

31. L. A. Emelity, et al. Disposal of ${ }^{241} \mathrm{Am}^{2}{ }^{39} \mathrm{Pu}$ Raffinate Solutions by Fixation with Cement. USAEC Report LA-3150-MS, Los Alamos Scientific Laboratory, Los Alamos, N. M. (1965).

32. F. M. Lea. The Chemistry of Cement and Concrete. Third Edition, Chemical Pub1ishing.Co., Inc., New York (1971).

33. C. R. Tipton, Jr. (Ed.) Reactor Handbook, Volume 1, Materials. 2nd edition, p. 1104, Interscience Publishers, New York (1960).

34. J. L. McE1roy, K. J. Schneider, J. N. Hartley, J. E. Mendel, G. L. Richardson, R. W. McKee, and A. G. Blasewitz. Waste Solidification Program Summary Report, Volume II, Evaluation of WSEP High Level Waste Solidification Processes. USAEC Report BNWL-1667, Pacific Northwest Laboratories, Battelle Memoria1 Institute, Rich1and, Washington (1972).

35. J. L. Nelson and B. W. Mercer. Ion Exchange Separation of Cesium from Waste Supermatant Solutions. USAEC Report HW76449, General Electric Co., Hanford Atomic Products Operation, Richland, Washington (1963). 